\title{
Diabetic Neuropathies: Diagnosis and Management
}

\author{
Gabriella Deli $^{a}$ Edit Bosnyak ${ }^{a} \quad G^{2}$ abriella Pusch ${ }^{a}$ b Samuel Komoly ${ }^{a}$ \\ Gergely Feher ${ }^{a, b}$

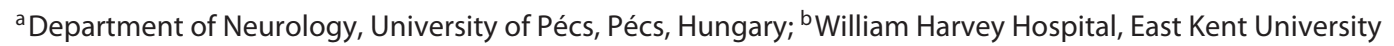 \\ NHS Foundation Trust, Ashford, UK
}

\section{Key Words}

Diabetes · Polyneuropathy · Neuropathy · Diagnosis .

Treatment $\cdot$ Neuropathic pain $\cdot$ Sensory neuropathy .

Autonomic neuropathy

\begin{abstract}
Introduction: Changes in human behaviour and lifestyle over the last century have resulted in a dramatic increase in the incidence of diabetes worldwide. Neuropathy is a common and costly complication of both type 1 and type 2 diabetes. The prevalence of neuropathy is estimated to be about $8 \%$ in newly diagnosed patients and greater than $50 \%$ in patients with long-standing disease. There are two main types of diabetic neuropathies, named as sensorimotor and autonomic neuropathies. Sensorimotor neuropathy is marked by pain, paraesthesia and sensory loss, and autonomic neuropathy may contribute to myocardial infarction, malignant arrhythmia and sudden death. Methods: In this article we reviewed the pathogenesis, clinical manifestations diagnosis and treatment of diabetic neuropathies. Conclusion: Sensorimotor and autonomic neuropathies (cardiovascular, gastrointestinal and genitourinary autonomic neuropathies) are common in diabetic patients. Apart from strict glycaemic control, no further therapeutic ap-
\end{abstract}

proach exists in the prevention of this phenomenon. Intensive diabetes therapy, intensive multifactorial cardiovascular risk reduction and lifestyle intervention are recommended in patients with cardiovascular autonomic neuropathy. Gastroparesis is the most debilitating complication of gastrointestinal autonomic neuropathy and genitourinary autonomic neuropathy can cause sexual dysfunction and neurogenic bladder; these conditions are hard to manage. The symptomatic treatment of sensory symptoms includes tricyclic antidepressants, serotonin and norepinephrine reuptake inhibitors, gabapentin, pregabalin and opioids. Other treatment strategies are not so effective.

(c) 2014 S. Karger AG, Basel

\section{Introduction}

Changes in human behaviour and lifestyle over the last century have resulted in a dramatic increase in the incidence of diabetes worldwide. The epidemic is chiefly of type 2 diabetes and also the associated conditions known as 'diabesity' and 'metabolic syndrome' $[1,2]$. In conjunction with genetic susceptibility, particularly in certain ethnic groups, type 2 diabetes is brought on by environmental and behavioural factors such as a sedentary life-

\section{KARGER}

E-Mail karger@karger.com

www.karger.com/nen (c) 2014 S. Karger AG, Basel

0028-3835/14/0984-0267\$39.50/0
Gergely Feher

Richard Stevens Ward, William Harvey Hospital

East Kent Hospitals University NHS Foundation Trust

Kennington Road, Willesborough, Ashford, Kent TN24 0LZ (UK)

E-Mail fehergergely@nhs.net 
style, overly rich nutrition and obesity. The prevention of diabetes and control of its micro- and macrovascular complications will require an integrated, international approach if we are to see a significant reduction in the huge premature morbidity and mortality it causes [1].

Neuropathy is a common and costly complication of both type 1 and type 2 diabetes. The prevalence of neuropathy is estimated to be about $8 \%$ in newly diagnosed patients and greater than $50 \%$ in patients with longstanding disease $[2,3]$.

Sensorimotor neuropathy is marked by pain, paraesthesia and sensory loss (table 1). The different mechanisms involved in different pain sensations are still poorly understood, but there is ample evidence that abnormal discharges from diseased somatosensory neurons are responsible $[4,5]$. Spontaneous activity in the peripheral nociceptor system may also trigger central nervous system changes responsible for hyperalgesia and allodynia $[4,5]$.

Cardiovascular autonomic neuropathy (CAN) may contribute to myocardial infarction, malignant arrhythmia and sudden death. Gastroparesis is the most debilitating complication of gastrointestinal autonomic neuropathy. Genitourinary autonomic neuropathy can cause sexual dysfunction and neurogenic bladder [5].

The aim of our article was to summarize the aetiology, forms and potential therapeutic approaches of diabetic neuropathy.

\section{The Epidemiology and Pathophysiology of Diabetic Neuropathy}

Diabetic peripheral neuropathy (DPN) is a common complication estimated to affect $30-50 \%$ of individuals with diabetes [6]. The primary risk factor for DPN is hyperglycaemia $[2,6]$. Other independent risk factors include age, duration of disease, cigarette smoking, hypertension, elevated triglycerides, higher BMI, alcohol consumption, and taller height $[2,6]$.

Interestingly, between 25 and $62 \%$ of patients with idiopathic peripheral neuropathy are reported to have prediabetes; among these $11-25 \%$ are thought to have peripheral neuropathy, and $13-21 \%$ have neuropathic pain [7]. Population-based studies suggest a gradient for the prevalence of neuropathy, being highest in patients with manifest diabetes mellitus, followed by individuals with impaired glucose tolerance, then by subjects with impaired fasting glucose and, finally, least in those with normoglycaemia [7].
It is generally believed that oxidative stress is the key pathological process inducing nerve damage in diabetes [8-10]. Oxidative stress, possibly triggered by vascular abnormalities and associated microangiopathy in the nerve, is a key pathological process inducing nerve damage in diabetes in humans and experimental models [2, $4,8]$. Diabetes-induced oxidative stress in animal models of type 1, type 2 and pre-diabetes in sensory neurons and peripheral nerves is demonstrated by increased production of reactive oxygen species, lipid peroxidation and protein nitrosylation, and diminished levels of reduced glutathione and ascorbate [2, 4, 8]. Treatment with antioxidants such as $\alpha$-lipoic acid, $\gamma$-linolenic acid and aldose reductase inhibitors prevent many indices of neuropathy in streptozotocin-diabetic rats $[2,4,7-10]$. The neurons and Schwann cells initiate protective mechanisms involving upregulation of antioxidant pathways; however, the neurodegenerative outcome is energy failure in the nerve, observed as a decrease in high-energy intermediates (e.g. phosphocreatine), impaired axonal transport of proteins and suboptimal ion pumping $[2,4$, 7-12] (fig. 1).

Sensing ongoing spontaneous pain and paroxysmal shooting pain in the absence of any external stimulus is caused by ectopic impulse generation within the nociceptive pathways [13]. The enhanced excitability can result from altered ion channel function such as an increase in persistent sodium currents. Persistent sodium currents can be reliably estimated using threshold tracking. In peripheral neuropathy, persistent sodium currents usually increase, possibly due to over-expression of sodium channels associated with axonal regeneration, and could be responsible for ectopic firings [14]. In diabetic neuropathy, the activation of the polyol pathway mediated by an enzyme, aldose reductase, leads to reduced $\mathrm{Na}^{+} / \mathrm{K}^{+}$pump activity and intra-axonal sodium accumulation; sodium currents are reduced presumably due to decreased transaxonal sodium gradient [14]. In addition to voltage-gated sodium channels, several other ion channels probably undergo alterations after a nerve lesion, such as voltage-gated potassium channels, which might also contribute to changes in membrane excitability of nociceptive nerves $[13,15]$.

Nerve injury also induces upregulation of various receptor proteins such as the transient receptor potential $\mathrm{V}_{1}$, which is activated by heat at about $41^{\circ} \mathrm{C}[13,16]$. In neuropathic condition the transient receptor potential $\mathrm{V}_{1}$ is downregulated on affected/injured fibres, but upregulated on uninjured $\mathrm{C}$ fibres, thereby causing spontaneous nerve activity induced by normal body temperature [13] 
Table 1. Definition and assessment of negative and positive sensory symptoms and signs in patients with neuropathic pain [based on 13]

\begin{tabular}{|c|c|c|}
\hline Symptom & Sign & Assessment \\
\hline \multicolumn{3}{|l|}{ Negative signs and symptoms } \\
\hline & Reduced sensation to: & Touch skin with: \\
\hline Hypoaesthesia & Non-painful stimuli & Painter's brush, cotton swab \\
\hline Pallhypoaesthesia & Vibration & Tuning fork \\
\hline Hypoalgesia & Painful stimuli & Pinprick \\
\hline Thermohypoaesthesia & Cold or warm stimuli & Objects of 10 and $45^{\circ} \mathrm{C}$ \\
\hline \multicolumn{3}{|l|}{ Spontaneous sensations/pain } \\
\hline Paraesthesia & Non-painful ongoing sensation & Number per episode \\
\hline Paroxysmal pain & Painful, shooting electrical attacks for seconds & Grade intensity $(0-10)$ \\
\hline Superficial pain & Painful ongoing sensation & $\begin{array}{l}\text { Threshold for evocation } \\
\text { Area in } \mathrm{cm}^{2}\end{array}$ \\
\hline \multicolumn{3}{|l|}{ Evoked pain } \\
\hline Mechanical dynamic allodynia & Normally non-painful stimuli on skin evoke pain & Stroking skin with painter's brush, etc. \\
\hline Mechanical static allodynia & $\begin{array}{l}\text { Normally non-painful pressure stimuli on skin } \\
\text { evoke pain }\end{array}$ & $\begin{array}{l}\text { Manual gentle mechanical pressure to } \\
\text { the skin }\end{array}$ \\
\hline $\begin{array}{l}\text { Mechanical punctate or pinprick } \\
\text { hyperalgesia }\end{array}$ & $\begin{array}{l}\text { Normally stinging-but-not-painful stimuli evoke } \\
\text { pain }\end{array}$ & Manual gentle pricking of the skin \\
\hline Temporal summation & $\begin{array}{l}\text { Repetitive application of identical single noxious } \\
\text { stimuli is perceived as increasing pain sensation }\end{array}$ & $\begin{array}{l}\text { Pricking the skin with safety pin at } \\
<3 \text {-second intervals for } 30 \mathrm{~s}\end{array}$ \\
\hline Cold allodynia & Normally non-painful cold stimuli evoke pain & Touch skin with objects of $20^{\circ} \mathrm{C}$ \\
\hline Heat allodynia & Normally non-painful heat stimuli evoke pain & Touch skin with objects of $40^{\circ} \mathrm{C}$ \\
\hline $\begin{array}{l}\text { Mechanical deep somatic } \\
\text { allodynia }\end{array}$ & $\begin{array}{l}\text { Normally non-painful pressure on deep somatic } \\
\text { tissues evokes pain }\end{array}$ & Manual light pressure at joints or muscle \\
\hline
\end{tabular}

Fig. 1. The pathogenesis of diabetic neuropathy [based on 5]. AGE = Advanced glycation end product; RAGE = receptors for AGEs.

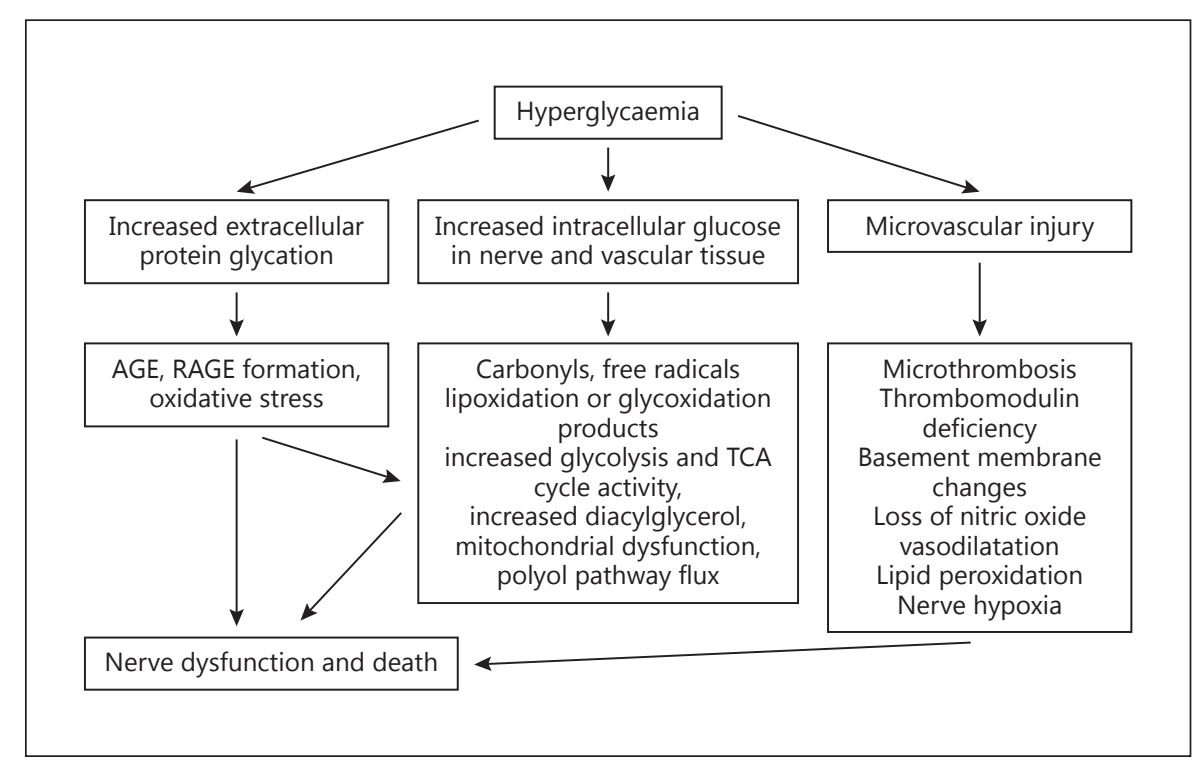

Central sensitization might develop as a consequence of ectopic activity in primary nociceptive afferent fibres and structural damage within the central nervous system itself might not be necessarily involved [13]. Spinal cord microglia are also strongly activated after nerve injury, the activated microglia not only exhibit increased expression of microglial markers CD11b and Iba1, but also display elevated phosphorylation of p38 mitogen-activated protein kinase. Inhibition of spinal cord p38 has been shown to attenuate neuropathic and postoperative pain, 
as well as morphine-induced antinociceptive tolerance. Activation of p38 in spinal microglia results in increased synthesis and release of the neurotrophin brain-derived neurotrophic factor and the proinflammatory cytokines interleukin-1 $\beta$, interleukin-6, and tumour necrosis factor- $\alpha$. Phosphorylation of N-methyl-D-aspartate and aminomethyl phosphonic acid receptors or expression of voltage-gated sodium channels are also involved both in the spinal cord and supraspinal structures. These mediators can powerfully modulate spinal cord synaptic transmission, leading to increased excitability of dorsal horn neurons (central sensitization), partly via suppressing inhibitory synaptic transmission [17].

Further potent inhibitory neurons, such as descending pathways originating in the brainstem, contribute to modulation of pain processing. Lesions that affect these opiodergic and monoaminergic systems also lead to pain exacerbation via disinhibition $[13,17]$.

\section{Forms of Diabetic Neuropathy}

Several fairly distinct clinical syndromes of diabetic neuropathy have been delineated. The most common, as noted, is a distal, symmetrical, primarily sensory polyneuropathy affecting feet and legs in a chronic, slowly progressive manner. The others are as follows: acute ophthalmoplegia that affects the third, and less often the sixth, cranial nerve on one side; acute mononeuropathy of limbs or trunk including a painful thoracolumbar radiculopathy; an acute or subacute painful, asymmetrical, predominantly motor multiple neuropathy affecting the upper lumbar roots and the proximal leg muscles ('diabetic amyotrophy'); a more symmetrical, proximal motor weakness and wasting, usually without pain and with variable sensory loss, pursuing a subacute or chronic course, and an autonomic neuropathy involving bowel, bladder, sweating and circulatory reflexes. These forms of neuropathy often coexist or overlap, particularly the autonomic and distal symmetrical types and the subacute proximal neuropathies (tables 2 and 3 ).

\section{Sensorimotor Neuropathy}

Distal Sensory Diabetic Polyneuropathy

This is the most common presentation of neuropathy in diabetes, and up to $50 \%$ of patients may experience symptoms - most frequently burning pain, electrical or stabbing sensations, paraesthesia, hyperaesthesia, and deep aching pain [3]. These symptoms are generally worse at night and disturb sleep. Together with painful symptoms during the day, this often leads to a reduction in the individual's ability to perform daily activities [18].

Examination of the lower limb usually reveals sensory loss of vibration, pressure, pain and temperature perception (mediated by small and large fibres), as well as absent ankle reflexes $[3,19]$. Muscle weakness is usually mild, but in some patients a distal sensory neuropathy is combined with a proximal weakness and wasting [19].

Interestingly, as up to half of the patients may be asymptomatic, a diagnosis may only be made on examination or, in some cases, when the patient presents with a painless foot ulcer [3].

Up to one third (10-35\%) of all community-based diabetic patients can have painful neuropathy symptoms [18-22]. Some patients develop predominantly small-fibre neuropathy manifesting with pain and paraesthesia early in the course of diabetes that may be associated with antiglycaemic (insulin and hypoglycaemic drugs) therapy (so-called insulin neuritis) [20].

\section{Acute Diabetic Mononeuropathies}

Cranial neuropathy in diabetic patients most commonly involves the oculomotor nerve followed by the trochlear and facial nerve in order of frequency. Thirdnerve palsy with pupillary sparing is the hallmark of diabetic oculomotor palsy and is attributed to nerve infarction [20].

Isolated involvement of practically all the major peripheral nerves has been described in diabetes (for example carpal tunnel syndrome is 3 times more common in diabetic patients than the normal population and is the second most common neuropathic disease in diabetic patients), but the ones most frequently affected are the femoral, sciatic and peroneal nerves, in that order $[19,20,23]$. Rarely is a nerve in the upper extremity affected $[19,20]$. In these cases nerve entrapment seems to be more common than nerve infarction [20].

Mononeuropathies often emerge during periods of transition in the diabetic illness, for example after an episode of hyper- or hypoglycaemia, when insulin treatment is initiated or adjusted, or when there has been rapid weight loss [19].

\section{Diabetic Multiple Mononeuropathies and}

Radiculopathies

This category overlaps with the mononeuropathies. A syndrome of painful unilateral or asymmetrical multiple neuropathies tends to occur in older patients with relatively mild or even unrecognized diabetes. Multiple 
Table 2. Signs, diagnosis and treatment of diabetic autonomic neuropathies [based on 3]

\begin{tabular}{|c|c|c|c|c|c|c|}
\hline & Cardiac & Gastrointestinal & $\begin{array}{l}\text { Sexual } \\
\text { dysfunction }\end{array}$ & $\begin{array}{l}\text { Bladder } \\
\text { dysfunction }\end{array}$ & $\begin{array}{l}\text { Sudomotor } \\
\text { (sweating) } \\
\text { dysfunction }\end{array}$ & Pupillomotor \\
\hline Symptoms & $\begin{array}{l}\text { Exercise intolerance, early } \\
\text { fatigue and weakness with } \\
\text { exercise } \\
\text { Postural hypotension, } \\
\text { dizziness, light-headedness, } \\
\text { weakness, fatigue, syncope }\end{array}$ & $\begin{array}{l}\text { Gastroparesis, erratic glucose } \\
\text { control } \\
\text { Abdominal pain or } \\
\text { discomfort, early satiety, } \\
\text { nausea, vomiting, belching, } \\
\text { bloating } \\
\text { Constipation } \\
\text { Diarrhoea, often nocturnal } \\
\text { alternating with constipation } \\
\text { and incontinence }\end{array}$ & $\begin{array}{l}\text { ED } \\
\text { Vaginal dryness }\end{array}$ & $\begin{array}{l}\text { Frequency, } \\
\text { urgency, } \\
\text { nocturia, urinary } \\
\text { retention, } \\
\text { incontinence }\end{array}$ & $\begin{array}{l}\text { Anhidrosis, } \\
\text { heat intolerance, } \\
\text { dry skin, } \\
\text { hyperhidrosis }\end{array}$ & $\begin{array}{l}\text { Visual blurring, } \\
\text { impaired } \\
\text { adaptation to } \\
\text { ambient light, } \\
\text { impaired visceral } \\
\text { sensation }\end{array}$ \\
\hline Tests & $\begin{array}{l}\text { HRV, multigated } \\
\text { angiography (MUGA) } \\
\text { thallium scan, 123I- } \\
\text { metaiodobenzylguanidine } \\
\text { (MIBG) scan, measure blood } \\
\text { pressure standing and supine, } \\
\text { measure catecholamines }\end{array}$ & $\begin{array}{l}\text { Gastric emptying study, } \\
\text { barium study } \\
\text { Endoscopy, manometry, } \\
\text { electrogastrogram }\end{array}$ & $\begin{array}{l}\text { History and } \\
\text { physical } \\
\text { examination, } \\
\text { HRV, } \\
\text { penile-brachial } \\
\text { pressure index, } \\
\text { nocturnal penile } \\
\text { tumescence }\end{array}$ & $\begin{array}{l}\text { Cystometrogram, } \\
\text { post-void } \\
\text { sonography }\end{array}$ & $\begin{array}{l}\text { Quantitative } \\
\text { sudomotor axon } \\
\text { reflex, sweat test, } \\
\text { skin blood flow }\end{array}$ & $\begin{array}{l}\text { Pupillometry, } \\
\text { HRV }\end{array}$ \\
\hline Treatments & $\begin{array}{l}\text { Graded supervised exercise, } \\
\text { ACE inhibitors, } \beta \text {-blockers } \\
\text { Mechanical measures, } \\
\text { clonidine, midodrine, } \\
\text { octreotide }\end{array}$ & $\begin{array}{l}\text { Frequent small meals, } \\
\text { prokinetic agents } \\
\text { (metoclopramide, } \\
\text { domperidone, erythromycin) } \\
\text { Antibiotics, antiemetics } \\
\text { (Phenergan, Compazine, } \\
\text { Tigan, scopolamine), } \\
\text { bulking agents, tricyclic } \\
\text { antidepressants, pancreatic } \\
\text { extracts, pyloric Botox, gastric } \\
\text { pacing, enteral feeding }\end{array}$ & $\begin{array}{l}\text { Sex therapy, } \\
\text { psychological } \\
\text { counseling, } \\
\text { sildenafil, } \\
\text { vardenafil, } \\
\text { tadalafil, } \\
\text { prostaglandin E1 } \\
\text { injection, device } \\
\text { or prosthesis } \\
\text { Vaginal } \\
\text { lubricants }\end{array}$ & $\begin{array}{l}\text { Bethanechol, } \\
\text { intermittent } \\
\text { catheterization }\end{array}$ & $\begin{array}{l}\text { Emollients and } \\
\text { skin lubricants, } \\
\text { scopolamine, } \\
\text { glycopyrrolate, } \\
\text { botulinum toxin, } \\
\text { vasodilators }\end{array}$ & $\begin{array}{l}\text { Care with } \\
\text { driving at night, } \\
\text { recognition of } \\
\text { unusual } \\
\text { presentations of } \\
\text { myocardial } \\
\text { infarction }\end{array}$ \\
\hline
\end{tabular}

$\mathrm{HRV}=\mathrm{Heart}$ rate variability; $\mathrm{ACE}=$ angiotensin-converting enzyme.

Table 3. The main features of different patterns of disabling neuropathies in patients with diabetes [based on 50]

\begin{tabular}{|c|c|c|c|c|c|c|c|c|}
\hline Pain & $\begin{array}{l}\text { Distal symmetrical } \\
\text { sensory loss }\end{array}$ & Weakness & $\begin{array}{l}\text { Sensory } \\
\text { ataxia }\end{array}$ & $\begin{array}{l}\text { Autonomic } \\
\text { dysfunction }\end{array}$ & Progression & $\begin{array}{l}\text { CSF } \\
\text { Protein }\end{array}$ & $\begin{array}{l}\text { Electro- } \\
\text { physiological } \\
\text { test }\end{array}$ & Nerve biopsy \\
\hline \multicolumn{9}{|c|}{ Length-dependent polyneuropathy } \\
\hline $\begin{array}{l}\text { Frequent in } \\
\text { distal limbs }\end{array}$ & $\begin{array}{l}\text { Length dependent - } \\
\text { predominates on pain } \\
\text { and temperature } \\
\text { sensations }\end{array}$ & $\begin{array}{l}\text { Minor, distal } \\
\text { symmetrical }\end{array}$ & Rare & Common & Years & Variable & $\begin{array}{l}\text { Axonal pattern, } \\
\text { distal } \\
\text { symmetrical }\end{array}$ & $\begin{array}{l}\text { Massive axonal } \\
\text { loss }\end{array}$ \\
\hline \multicolumn{9}{|c|}{ CIDP in diabetic patients } \\
\hline Occasional & $\begin{array}{l}\text { Variable - } \\
\text { predominates on } \\
\text { proprioception }\end{array}$ & $\begin{array}{l}\text { Common, often } \\
\text { severe proximal } \\
\text { and distal }\end{array}$ & Common & Uncommon & $\begin{array}{l}\text { Weeks or } \\
\text { months }\end{array}$ & Increased & $\begin{array}{l}\text { Mixed axonal } \\
\text { and } \\
\text { demyelinative }\end{array}$ & $\begin{array}{l}\text { Variable axon } \\
\text { loss and } \\
\text { demyelination }\end{array}$ \\
\hline \multicolumn{9}{|c|}{ Focal/multifocal diabetic neuropathy } \\
\hline $\begin{array}{l}\text { Present in } \\
\text { most cases }\end{array}$ & Variable & $\begin{array}{l}\text { Common - } \\
\text { asymmetrical - } \\
\text { nerve or root } \\
\text { territory }\end{array}$ & Uncommon & Uncommon & $\begin{array}{l}\text { Weeks or } \\
\text { months }\end{array}$ & Increased & $\begin{array}{l}\text { Axonal pattern, } \\
\text { multifocal }\end{array}$ & Variable \\
\hline
\end{tabular}

CIDP = Chronic inflammatory demyelinating polyneuropathy; CSF = cerebrospinal fluid.

Diabetic Neuropathies: Diagnosis and Management 
nerves are affected in a random distribution (mononeuritis multiplex). As in mononeuropathy the onset is abrupt in one nerve and occurs earlier than the other nerves, which are involved sequentially or irregularly. Nerve infarctions occur because of occlusion of the vasa nervosum and should be differentiated from systemic vasculitis [20].

There are characteristic diabetic syndromes, which present subacutely with pain followed by weakness and primarily affect patients with mild diabetes, called radiculoplexus neuropathies (table 3 ). Three main types can occur, alone or in combination, and include diabetic cervical radiculoplexus neuropathy, diabetic thoracic radiculoneuropathy and diabetic lumbosacral radiculoplexus neuropathy [23].

Diabetic lumbosacral radiculoplexus neuropathy occurs in approximately $1 \%$ of diabetic patients and is probably the form of diabetic neuropathy that causes the most morbidity $[23,24]$. It has been variably known by different names, including diabetic amyotrophy, Bruns-Garland syndrome, diabetic mononeuritis multiplex, diabetic polyradiculopathy, proximal diabetic neuropathy, and others $[19,23]$. Pain, which can be severe, begins in the lower back or hip and spreads to the thigh and knee on one side; the discomfort has a deep, aching character with superimposed lancinating jabs and there is a propensity for pain to be most severe at night. Although pain is initially the worst symptom, weakness and atrophy become the main problem, which are mainly evident in the pelvic girdle and thigh muscles, although the distal muscles of the leg may also be affected $[19,20,23]$.

Diabetic thoracic radiculopathies are a rare but important complication of diabetes mellitus. These typically present with severe pain and dysaesthesia along the trunk, chest or abdominal wall, and often prompt extensive workups for underlying chest or abdominal pathology $[19,23]$. They can be symmetrical and can involve multiple dermatomes [21]. While diabetic lumbosacral radiculoplexus neuropathy is a much more familiar branch of the radiculoplexus neuropathy spectrum, the cervical segment can also be involved, but this is very rare $[19,23]$.

\section{Autonomic Neuropathy}

Diabetic autonomic neuropathy is a widespread disorder of the cholinergic, adrenergic and peptidergic autonomic fibres in the context of diabetes without other causes. It is characterized by a subclinical form that is detectable only by tests, and a clinical form with the presence of signs and symptoms [25] (table 2).
Cardiovascular Autonomic Neuropathy

CAN is defined as the impairment of autonomic control of the cardiovascular system. In diabetes, CAN is ultimately the result of complex interactions among degree of glycaemic control, disease duration, age-related neuronal attrition and systolic and diastolic blood pressure [25]. Hyperglycaemia plays the key role in the activation of various biochemical pathways related to the metabolic and/or redox state of the cell, which, in concert with impaired nerve perfusion, contribute to the development and progression of diabetic neuropathies [24]. Because neuropathy is seen first in the longest fibres, the earliest manifestations of autonomic neuropathy in diabetes tend to be associated with parasympathetic denervation, with consequent early augmentation of sympathetic tone. Clinical symptoms of autonomic dysfunction may not appear until long after diabetes onset. However, subclinical CAN may be detected within 1 year of diagnosis in type 2 diabetes and within 2 years of diagnosis in type 1 diabetes [24].

The signs of this disease are impaired heart rate variability, resting tachycardia, exercise intolerance, abnormal blood pressure regulation and orthostatic hypotension [26-28] (table 2). CAN is significantly associated with overall mortality and in some - but not all - studies with morbidity such as silent myocardial ischaemia, coronary artery disease, stroke, diabetic nephropathy progression and perioperative morbidity. Thus, CAN assessment may be used for cardiovascular risk stratification in patients with and without established cardiovascular disease [26].

\section{Gastrointestinal Autonomic Neuropathy}

Gastrointestinal motor, sensory and secretory functions are modulated by the interaction of the autonomic (sympathetic and parasympathetic) and enteric nervous systems with underlying rhythmicity generated by the interstitial cells of Cajal located within the smooth muscle. Evaluation of gastrointestinal autonomic function is difficult in humans, and the diagnosis of gastrointestinal autonomic neuropathy is often one of exclusion $[3,25$, 26]. Diabetes is associated with gastrointestinal symptoms such as nausea, bloating, abdominal pain, diarrhoea, constipation and delayed gastric emptying with concomitant impaired oral drug absorption, poor glycaemic control, malnutrition, abnormal postprandial regulation of blood pressure, poor quality of life, and a high rate of hospitalization [3,24-27]. Up to $75 \%$ of patients with diabetes can experience these symptoms [27]. 


\section{Erectile Dysfunction}

Erectile dysfunction (ED) affects $30-40 \%$ of diabetic men and occurs as a result of endothelial dysfunction and autonomic neuropathy. The close association with endothelial dysfunction means ED is an early marker of cardiovascular risk. Although there are some effective treatments for ED, the management of this condition sometimes is extremely difficult. It is recommended to be part of a diabetes care service. There has been much recent interest in the potential relationship between late-onset hypogonadism and diabetes, but there is no evidence of a causal relationship and the evidence in favour of treating borderline hypogonadism in diabetes is limited [28]. Effective treatment of ED requires recognition of the condition and its associated comorbidities, including endothelial dysfunction [29].

\section{Diabetic Bladder Dysfunction}

Estimates of the prevalence of bladder dysfunction are $43-87 \%$ of type 1 diabetic patients and $25 \%$ of type 2 diabetic patients $[3,22,26]$. The cause of bladder dysfunction in diabetes mellitus is primarily peripheral and autonomic neuropathy. Animal and human studies have revealed that diabetic cystopathy develops as a result of polyneuropathy, which predominantly affects sensory and autonomic nerve fibres [30].

Patients often remain asymptomatic in early stages despite demonstrable bladder abnormality. Impaired bladder sensation is usually the first manifestation of lower urinary tract involvement. Micturition reflexes are delayed due to diminished bladder sensation with increases in bladder capacity and urinary retention that usually occur asymptomatically $[26,30]$. Patients are frequently unaware of bladder dysfunction until they have a urinary tract infection secondary to increased residual urine volume $[3,26,30]$. The common symptoms are straining, hesitation and weakness of stream [26, 30]. Diabetic cystopathy is characterized by impaired sensation of bladder fullness, which leads to overstretched bladder, reduced bladder contractility, increased residual urine and impaired uroflow [30].

\section{Diabetic Sudomotor Dysfunction}

Diabetic autonomic neuropathy initially results in a loss of thermoregulatory sweating in a 'glove and stocking' distribution that can extend to the upper parts of the limbs and the anterior abdomen, conforming to the wellrecognised length dependency of diabetic neuropathy. This process ultimately results in global anhidrosis that generally accompanies a severe autonomic neuropathy

Diabetic Neuropathies: Diagnosis and Management
[31]. Diabetic autonomic neuropathy can also cause hyperhidrosis. Excessive sweating could occur as a compensatory process, involving proximal regions such as the head and trunk that are spared in a dying-back neuropathy. Gustatory sweating, abnormal production of sweat that appears over the face, head, neck, shoulders and chest after consumption of even non-spicy foods, occurs in occasional cases [31].

\section{Diagnostic Procedures}

\section{Diagnosis of Pre-Diabetes and Diabetes Mellitus}

It has been previously shown that pre-diabetes can also be associated with neuropathy. Based on the recent ADA guidelines, diabetes can be diagnosed on the results of HgbA1c, fasting plasma glucose or 2-hour postprandial glucose levels. This statement recommended the use of the Alc test to diagnose diabetes, with a threshold of $\geq 6.5 \%$. The established glucose criteria for the diagnosis of diabetes (fasting plasma glucose $\geq 7 \mathrm{mmol} / \mathrm{l}$ or 2 -hour postprandial glucose $\geq 11.1 \mathrm{mmol} / \mathrm{l}$ ) remained valid as well [32].

Pre-diabetes can be defined as having impaired fasting glucose (fasting plasma glucose levels $5.6-6.9 \mathrm{mmol} / \mathrm{l}$ ) or impaired glucose tolerance (2-hour postprandial glucose values in the oral glucose tolerance test of $7.8-11.0 \mathrm{mmol} / \mathrm{l}$ ). It should be noted that the World Health Organization and a number of other diabetes organizations define the cut-off for impaired fasting glucose at $110 \mathrm{mg} / \mathrm{dl}(6.1 \mathrm{mmol} / \mathrm{l})$ [32]. Hence, it is reasonable to consider an A1c range of $5.7-6.4 \%$ as identifying individuals with high risk for future diabetes, a state that may be referred to as pre-diabetes [32]. As with glucose measurements, the continuum of risk is curvilinear - as A1c rises, the risk of diabetes rises disproportionately [32]. Accordingly, interventions should be most intensive and follow-up particularly vigilant for those with A1c $>6.0 \%$, who should be considered to be at very high risk [32]. Standards of lifestyle and medical care can also be found in this guideline [32].

\section{Diagnosis of Sensorimotor Neuropathy}

In DPN, sensory deficits usually overshadow motor nerve dysfunction and appear first in the distal portions of the extremities and progress proximally in a 'stockingglove' distribution with increasing duration or severity of diabetes [2]. In the typical form, the large nerve fibres are damaged later than the small ones [33]. The signs and symptoms of DPN vary depending on fibre type involved, with large fibre disease impairing proprioception and light touch. Small-fibre disease impairs pain and temper- 
ature perception, leading to paraesthesia, dysaesthesia and/or neuropathic pain [2] (table 1). Distal weakness occurs only in the most severe cases. Diminished or absent deep-tendon reflexes, particularly the Achilles tendon reflex, often indicate mild and otherwise asymptomatic DPN. More advanced asymptomatic neuropathy may first present with late complications such as ulceration or neuroarthropathy (Charcot's joints) of the foot [2].

For diagnosis of DPN, bedside examination should include assessment of muscle power, sensations of pinprick, joint position, touch and temperature. Vibration test should be done by a $128-\mathrm{Hz}$ tuning fork. For touch sensation monofilament of $10 \mathrm{~g}$ is recommended $[13,20]$. A number of questionnaires have been developed to help practitioners diagnose neuropathic pain [13, 20,33]. The DN4 questionnaire is of particular interest as it can be rapidly completed, is easy to use and has a good diagnostic performance: for a score $\geq 4 / 10$, it has a sensitivity of $83 \%$ and a specificity of $90 \%$ for diagnosing neuropathic pain [33]. The main advantage of screening tools is to identify potential patients with neuropathy, particularly by non-specialists. However, these tools fail to identify $10-20 \%$ of patients with clinician-diagnosed neuropathy, showing that they cannot replace careful clinical judgement [34].

Electrophysiological tests are usually not recommended in the diagnosis of chronic sensorimotor diabetic neuropathy, as they can be normal when only small-diameter fibres are damaged, but it is a reliable procedure in the case of mononeuropathies or radiculopathies to exclude any other aetiology (demyelinating polyneuropathies, etc.). Such procedures are really useful when the clinical presentation is atypical and the diabetic origin uncertain (asymmetrical symptoms or involvement of the upper limbs) $[20,26,33]$.

Among laboratory tests, laser-evoked potentials may be the best tool for assessing $A \delta$ pathway dysfunction (smallfibre neuropathy), and skin biopsy for assessing neuropathies with distal loss of unmyelinated nerve fibres [34].

\section{Diagnosis of Autonomic Neuropathy}

Questionnaires have been developed to investigate orthostatic symptoms and their severity in dysautonomic conditions, although they have not been specifically validated for CAN and validated translations in different languages are lacking [35].

Diabetic patients with features of cardiac autonomic dysfunction such as unexplained tachycardia, orthostatic hypotension and poor exercise tolerance, or with other symptoms of autonomic dysfunction, should be evaluated for the presence of CAN. Screening for CAN should be performed at the diagnosis of type 2 diabetes and 5 years after the diagnosis of type 1 diabetes, particularly in patients at greater risk of CAN due to a history of poor glycaemic control, cardiovascular risk factors, DPN, and macro- and microangiopathic diabetic complications [26]. Diagnosis of CAN is based on the use of cardiovascular autonomic reflex tests for heart rate response to deep breathing, standing and Valsalva manoeuvre, as well as for blood pressure response to standing [26, 35] (table 2).

A number of instruments are available to quantify gastrointestinal symptoms, including the Diabetes Bowel Symptom Questionnaire. Objective gastric emptying measurement is advocated for the diagnosis of gastroparesis. Unfortunately, there is no specific test in the detection of diabetic gastroparesis - it is only an exclusion diagnosis after detailed gastrointestinal examinations [26].

Key diagnostic procedures of ED include comprehensive patient history (sexual, medical, drugs, alcohol, tobacco and psychosocial). The use of validated questionnaires is the most appropriate method to characterize the frequency and severity of ED symptoms [26]. Due to the potential risks of adverse or unanticipated drug interactions, cardiac risk factors should be evaluated and managed in all patients with ED and cardiovascular disease [26]. Specific testing may be recommended in patients not responding to phosphodiesterase-5 inhibitors [26].

The type of bladder dysfunction is most readily characterized with complete urodynamic testing [26]. Assessment of sudomotor dysfunction contributes to the detection of autonomic dysfunction in DPN. The quantitative sudomotor axon reflex test is capable of detecting distal small-fibre polyneuropathy with a sensitivity of 75\% [26] (table 2).

\section{Treatment of Diabetic Neuropathy}

In diabetic patients the risk of DPN and autonomic neuropathy can be reduced with improved blood glucose control, and the improvement of lipid and blood pressure indexes and the avoidance of cigarette smoking and excess alcohol consumption are already recommended for the prevention of other complications of diabetes $[32,33]$.

\section{Preventive Treatment}

Based on the aetiology of diabetic neuropathy several agents have been tested to halt its progression (after the onset of subjective symptoms, only palliative treatments are currently available), thereby improving clinical out- 
come [36]. An analysis of the literature on experimental peripheral diabetic neuropathy suggests that, to date, all of the pharmacological agents shown to counteract one or several manifestations of painful or insensate neuropathy also have efficacy against nerve conduction velocity deficit [36]. Animal studies using pharmacological and genetic approaches revealed important roles of increased aldose reductase, protein kinase $\mathrm{C}$, poly(ADP-ribose) polymerase activities, advanced glycation end products and their receptors, oxidative-nitrosative stress, growth factor imbalances, and C-peptide deficiency in both painful and insensate neuropathy [36].

It has been suggested, based on recent studies, that aldose reductase inhibitor treatment not only improved impaired conduction velocity but also improved a variety of subjective symptoms [37-40]. These findings may support the hypothesis that the polyol pathway plays a central role in the onset and progress of diabetic neuropathy in human subjects. On the other hand, a Cochrane metaanalysis including 32 trials found no overall significant difference between the treated and control groups (standardized mean difference: $-0.25,95 \%$ CI: -0.56 to 0.05 ), although one subgroup analysis (4 trials using tolrestat) favoured treatment [41]. There was no overall benefit on nerve conduction parameters (27 studies) or foot ulceration (1 study). Quality of life was not assessed in any of the studies. While most adverse events were infrequent and minor, three compounds had dose-limiting adverse events that led to their withdrawal from human use: severe hypersensitivity reactions with sorbinil, elevation of creatinine with zenarestat and alteration of liver function with tolrestat [41].

a-Lipoic acid is also a potent antioxidant in experimental models, and is reported to reduce diabetic microvascular and macrovascular complications in animal models [42]. A total of 4 trials (ALADIN I, ALADIN III, SYDNEY and NATHAN II) comprising 1,258 patients ( $\alpha$-lipoic acid, $n=716$; placebo, $n=542$ ) were included in the first meta-analysis based on the intention-to-treat principle. The results of this meta-analysis provided evidence that treatment with $\alpha$-lipoic acid $(600 \mathrm{mg}$ /day, i.v.) over 3 weeks is safe and significantly improves both positive neuropathic symptoms and neuropathic deficits to a clinically meaningful degree in diabetic patients with symptomatic polyneuropathy [43]. This statement was also included in the ADA guidelines as a level I, grade A evidence $[26,32]$. On the other hand, this meta-analysis did not fulfil the requirements of the Cochrane Collaboration [42]. From an economical point of view standard symptomatic treatment seems to be much cheaper in Eu-

Diabetic Neuropathies: Diagnosis and Management rope $[42,44]$. The combination of parenteral $(600 \mathrm{mg}$ daily for 3 weeks) and oral therapy (600 mg 3 times daily for 6 months) administered over a total of 7 months failed to translate into significant improvements [44, 45]. The 4-year follow-up NATHAN 1 trial also led to this neutral result [46]. A recent meta-analysis and a review confirmed the above-mentioned findings [47, 48]. The current American Academy of Neurology (AAN) and European Federation of Neurological Societies (EFNS) guidelines do not support the use of this drug in neuropathic conditions $[49,50]$.

Angiotensin-converting enzyme inhibitors or angiotensin receptor blockers are widely used in diabetic patients to manage blood pressure and to prevent or treat cardiovascular disease and nephropathy. Large-scale studies of the effects of angiotensin-converting enzyme inhibitors or angiotensin receptor blockers have not been done, although some small studies and prospective assessments have been performed with positive impact on neuropathy [2].

\section{Symptomatic Treatment - Painful Diabetic Neuropathy}

Tricyclic Antidepressants. Tricyclic antidepressants (TCAs) are so-called early antidepressant medications. These first-generation medications were effective in the treatment of depression because they enhanced serotonergic or noradrenergic mechanisms or both. They were also the first medication category that proved effective for neuropathic pain in placebo-controlled trials [51, 52]. Unfortunately, TCAs also blocked histaminic, cholinergic, and a1-adrenergic receptor sites, and this action brought about unwanted side effects such as weight gain, dry mouth, constipation, drowsiness and dizziness [51]. The cardiovascular effects of TCAs are well characterized and include orthostatic hypotension, slowed cardiac conduction, type $1 \mathrm{~A}$ antiarrhythmic activity and increased heart rate [52]. However, many of these have a temporary and mild effect and they are generally well tolerated. Based on a Cochrane analysis for diabetic neuropathy the number-needed-to-treat (NNT) for effectiveness was 1.3 (95\% CI: 1.2-1.5), the number-neededto-harm $(\mathrm{NNH})$ for minor adverse effects was 6 (95\% CI: 4.2-10.7) and NNH for major adverse effects (defined as an event leading to withdrawal from a study) was 28 (95\% CI: 17.6-68.9) [53]. Comparison metaanalysis of TCAs and selective serotonin reuptake inhibitors (SSRIs) showed beneficial safety profiles (but the key effects differed between the drug classes) [54, 55]. On the other hand, their use should be avoided in 
post-infarct states and in the case of conduction disturbances and cardiac arrhythmias (IA antiarrhythmic effect) [54-56] (table 4).

Selective Serotonin Reuptake Inhibitors. The SSRIs are increasingly being used to treat a spectrum of depressed patients, including the elderly. As a class, SSRIs have comparable efficacy to TCAs against depression but are generally better tolerated [57]. Despite their wide use there is still limited evidence for the role of classical SSRIs in the treatment of painful diabetic neuropathy [58-61].

The class of serotonin and norepinephrine reuptake inhibitors (SNRIs) now comprises three medications: venlafaxine, milnacipran and duloxetine. These drugs block the reuptake of both serotonin (5-HT) and norepinephrine with differing selectivity. Whereas milnacipran blocks 5-HT and norepinephrine reuptake with equal affinity, duloxetine has a 10 -fold selectivity for 5 -HT and venlafaxine a 30-fold selectivity for 5-HT. All three SNRIs are efficacious in treating a variety of anxiety disorders [62].

Venlafaxine (3 studies) has an NNT of 3.1 (95\% CI: 2.2-5.1). The NNH for minor adverse effects is 9.6 (95\% CI: 3.5-13) and that for major adverse effects is 16.2 (95\% CI: 8-436) [58].

Duloxetine at $60 \mathrm{mg}$ daily was also effective in treating painful DPN in the short term up to 12 weeks with a risk ratio for $50 \%$ pain reduction at 12 weeks of 1.65 (95\% CI: 1.34-2.03), and NNT of 6 (95\% CI: 5-10) [63]. In a side effect analysis it was generally safe and well tolerated, with the three most commonly reported adverse events being nausea, somnolence and constipation. Modest changes in glycaemia were associated with duloxetine. Aspartate transaminase/alanine transaminase increases were transient and not considered predictive of more severe outcomes [64] (table 4).

Antiepileptic Drugs. These have a long history of effectiveness in the treatment of neuropathic pain, dating back to case studies of the treatment of trigeminal neuralgia with phenytoin in 1942 and carbamazepine in 1962 [65]. Since 1993, nine new antiepileptic drugs (felbamate, gabapentin, pregabalin, lamotrigine, topiramate, tiagabine, levetiracetam, oxcarbazepine and zonisamide) have received FDA approval for the adjunctive treatment of partial seizures $[65,66]$. In addition to providing efficacy against epilepsy, these new antiepileptic drugs may also be effective in neuropathic pain. For example, spontaneous activity in regenerating small-calibre primary afferent nerve fibres may be quelled by sodium channel blockade, and hyperexcitability in dorsal horn spinal neurons may be decreased by the inhibition of glutamate release [65].
Gabapentin is an effective agent in the treatment of diabetic neuropathy; the NNT for effective pain was 2.9 (95\% CI: 2.2-4.3) and the NNH for minor harm was 3.7 (95\% CI: 2.4-5.4). Persons taking gabapentin can expect to suffer dizziness $(21 \%)$, somnolence $(16 \%)$, peripheral oedema (8\%) and gait disturbance (9\%). Serious adverse events $(4 \%)$ were no more common than with placebo $[67,68]$ (table 4).

Pregabalin at doses of 300, 450 and $600 \mathrm{mg}$ daily was effective in patients with postherpetic neuralgia, painful diabetic neuropathy, central neuropathic pain and fibromyalgia (19 studies, 7,003 participants). Pregabalin at $150 \mathrm{mg}$ daily was generally ineffective [9]. The best (lowest) NNT for each condition for at least $50 \%$ pain relief over baseline (substantial benefit) for $600 \mathrm{mg}$ pregabalin daily compared with placebo was 5.0 (4.0-6.6) for painful diabetic neuropathy. With $600 \mathrm{mg}$ pregabalin daily somnolence typically occurred in $15-25 \%$ and dizziness occurred in $27-46 \%$. The proportion of participants reporting at least one adverse event was not affected by dose, nor was the number with a serious adverse event, which was not more than with placebo [69] (table 4).

The efficacy of valproic acid and lamotrigine is doubtful and they are not recommended routinely $[70,71]$. Using the Cochrane criteria carbamazepine seems to be effective; on the other hand, no trial was longer than 4 weeks, of good reporting quality and used outcomes equivalent to at least moderate clinical benefit. In these circumstances, caution is needed in interpretation, and meaningful comparison with other interventions is not possible [72]. The efficacy of topiramate is also neutral in this condition $[73,74]$.

Narcotic Agents. Short-term studies provide only equivocal evidence regarding the efficacy of opioids in reducing the intensity of neuropathic pain, whereas intermediate-term studies demonstrate significant efficacy of opioids over placebo, which is likely to be clinically important [75]. The opioids studied were classified as weak (tramadol, propoxyphene and codeine) or strong (morphine and oxycodone) [76]. Weak and strong opioids outperformed placebo for pain and function in all types of neuropathic pain based on the result of a recent metaanalysis [76]. Other drugs produced better functional outcomes than opioids, whereas for pain relief they were outperformed only by strong opioids. Dropout rates averaged 33\% in the opioid groups and 38\% in the placebo groups [76]. Among the side effects of opioids, only constipation and nausea were clinically and statistically significant. 
Table 4. First-line treatment of neuropathic pain [based on $3,13,33,53,58,63$ ]

\begin{tabular}{|c|c|c|c|c|c|c|c|}
\hline Drug & Mode of action & Cautions & Major side effects & Other benefits & NNT & $\mathrm{NNH}$ & $\mathrm{NNMH}$ \\
\hline TCA & $\begin{array}{l}\text { Inhibition of reuptake of } \\
\text { serotonin and/or } \\
\text { norepinephrine, block of } \\
\text { sodium channels, } \\
\text { anticholinergic }\end{array}$ & Post-infarct states, arrhythmias & $\begin{array}{l}\text { Sedation, } \\
\text { anticholinergic } \\
\text { effects }\end{array}$ & $\begin{array}{l}\text { Improvement of } \\
\text { depression and } \\
\text { sleep disturbance }\end{array}$ & $1.3-2.4$ & $2.7-6.0$ & $15-28$ \\
\hline SNRI & $\begin{array}{l}\text { Inhibition of both serotonin } \\
\text { and norepinephrine reuptake }\end{array}$ & $\begin{array}{l}\text { Hepatic dysfunction, renal } \\
\text { insufficiency, alcoholism, } \\
\text { cardiac disease }\end{array}$ & Nausea & $\begin{array}{l}\text { Improvement of } \\
\text { depression }\end{array}$ & $3.1-6.0$ & 9.6 & $17-21$ \\
\hline Gabapentin & $\begin{array}{l}\text { Decreases release of glutamate, } \\
\text { norepinephrine, and substance } \\
\mathrm{P} \text {, with ligands on } \alpha 2-\delta \text { subunit } \\
\text { of voltage-gated calcium } \\
\text { channel }\end{array}$ & Renal insufficiency & $\begin{array}{l}\text { Sedation, dizziness, } \\
\text { peripheral oedema }\end{array}$ & $\begin{array}{l}\text { No clinically } \\
\text { significant drug } \\
\text { interactions }\end{array}$ & $3.3-5.8$ & $2.7-3.7$ & $11-23$ \\
\hline Opioids & $\begin{array}{l}\mu \text {-Receptor agonism, inhibition } \\
\text { of norepinephrine and } \\
\text { serotonin reuptake }\end{array}$ & $\begin{array}{l}\text { History of substance abuse, } \\
\text { suicide risk, driving } \\
\text { impairment, concomitant use } \\
\text { of SSNRI, tricyclic } \\
\text { antidepressant (serotonin } \\
\text { syndrome) }\end{array}$ & $\begin{array}{l}\text { Nausea/vomiting, } \\
\text { constipation, } \\
\text { dizziness }\end{array}$ & $\begin{array}{l}\text { No systemic side } \\
\text { effects and rapid } \\
\text { onset of analgesic } \\
\text { effect }\end{array}$ & $2.6-4.3$ & 3.6 & 7.8 \\
\hline
\end{tabular}

$\mathrm{NNMH}=$ Number needed to major harm.

Benzodiazepines. Agonists at the benzodiazepinebinding site of ionotropic $\mathrm{GABA}_{\mathrm{A}}$ receptors are in clinical use as hypnotics, anxiolytics and anticonvulsants since the early 1960. Analgesic effects of classical benzodiazepines have occasionally been reported in certain subgroups of patients suffering from chronic pain or after spinal delivery through intrathecal catheters. However, these drugs are generally not considered as analgesics. Recent evidence from genetically modified mice now indicates that agents targeting only a subset of benzodiazepine $\left(\mathrm{GABA}_{\mathrm{A}}\right)$ receptors should provide pronounced antihyperalgesic activity against inflammatory and neuropathic pain. Several such compounds have been developed recently, which exhibit significant antihyperalgesia in mice and rats and appear to be devoid of the typical side effects of classical benzodiazepines [77].

Other Agents. Local lidocaine and capsaicin cream have been shown to be effective in the treatment of neuropathic conditions [78]. They are included as potential therapeutic options in the recent AAN guidelines [49]. Acupuncture, but not traditional Chinese herbal medicine, seems to be slightly effective [79-81]. Transcutane-

Diabetic Neuropathies: Diagnosis and Management ous electric nerve stimulation should also be considered in the treatment of painful diabetic neuropathy [82].

Comparison. In random-effects and fixed-effects analyses of duloxetine, pregabalin and gabapentin, all were superior to placebo for all efficacy parameters, with some tolerability trade-offs. Indirect comparison of duloxetine with pregabalin found no differences in 24-hour pain severity, but significant differences in subjective global improvement (favouring pregabalin) and dizziness (favouring duloxetine) were apparent. Comparing duloxetine and gabapentin, there were no statistically significant differences [83]. In 3 head-to-head trials, there was no difference between gabapentin and TCAs for achieving pain relief (risk ratio: 0.99, 95\% CI: 0.76-1.29) [84]. In a recent network meta-analysis, all interventions remained effective in comparison with placebo. Mean difference in change of pain from baseline compared with placebo was as follows: amitriptyline: -12.58 (95\% CI: -16.66 to -8.50$)$; capsaicin: -9.40 (95\% CI: -13.92 to -4.88$)$; gabapentin: -10.22 (95\% CI: -17.25 to -3.19$)$; pregabalin: -10.53 (95\% CI: -14.74 to -6.32 ) [83]. Based on these results $5 \%$ lidocaine-medicated plaster was comparable to the previously mentioned medications [85]. 
Combination Therapy. Unfortunately there are too few controlled studies (complying with modern requirements for evidence-based medicine) on combination therapy for neuropathic pain [84]. Based on pharmacological and pharmacokinetical profile, SNRIs and TCAs cannot be combined because of the high possibility of serotonin syndrome. TCAs and gabapentin, pregabalin or SNRI in combination with the above-mentioned agents are good possibilities. Opioids can be combined with each of these drugs. Based on the recent AAN guidelines venlafaxine may be added to gabapentin for a better response and the EFNS guidelines prefer the combination therapy of TCAgabapentin and gabapentin opioids [32, 46].

The recently published COMBO-DN multicentre, double-blind, parallel-group study in diabetic peripheral neuropathic pain addressed whether, in patients not responding to standard doses of duloxetine or pregabalin, combining both medications is superior to increasing each drug to its maximum recommended dose [86]. For initial 8-week therapy, either $60 \mathrm{mg} /$ day duloxetine (groups 1 and 2) or $300 \mathrm{mg} /$ day pregabalin (groups 3, 4) was given. Thereafter, in the 8-week combination/highdose therapy period, only non-responders received 120 $\mathrm{mg} /$ day duloxetine (group 1), a combination of $60 \mathrm{mg}$ /day duloxetine and $300 \mathrm{mg} /$ day pregabalin (groups 2 and 3), or $600 \mathrm{mg}$ /day pregabalin (group 4). In total, 804 patients were evaluated for initial therapy and 339 for combination/high-dose therapy. The $50 \%$ response rates were $52.1 \%$ for combination and $39.3 \%$ for high-dose monotherapy $(\mathrm{p}=0.068)$. In exploratory analyses of the initial 8 -week therapy uncorrected for multiple comparisons, $60 \mathrm{mg} /$ day duloxetine was found superior to $300 \mathrm{mg} /$ day pregabalin $(\mathrm{p}<0.001)$ [86]. Although not significantly superior to high-dose monotherapy, combination therapy was considered to be effective, safe and well tolerated.

\section{Symptomatic Treatment - Autonomic Diabetic Neuropathy}

Intensive diabetes therapy, multifactorial cardiovascular risk reduction and lifestyle intervention are recommended in patients with CAN [35]. Resting tachycardia may be treated with $\beta$-blockers [35]. Symptomatic orthostatic hypotension may be improved by non-pharmacological measures and by midodrine and/or fludrocortisone [35]. Apart from the preventive role of intensive glycaemic control in type 1 diabetes, recommendations cannot be given for most therapeutic approaches to CAN [35].

Patients with disordered oesophageal motility associated with reflux should be managed conventionally, usually with proton pump inhibitors. In patients with symp- tomatic gastroparesis, low-fat/fibre diets are frequently advocated, but their use is empirical. Prokinetic drugs, including metoclopramide, erythromycin and domperidone, are the mainstay of treatment [87]. The management of diarrhoea, constipation and faecal incontinence is still largely symptomatic once specific causes like coeliac disease and exocrine pancreatic insufficiency are excluded. Bacterial overgrowth, implicated in up to $40 \%$ of diabetic patients with chronic diarrhoea, should be treated with antibiotics [87].

The treatment of ED is based on phosphodiesterase- 5 inhibitors [84].

\section{Conclusion}

Sensorimotor and cardiovascular neuropathies are common in diabetic patients. Apart from strict glycaemic control, no further therapeutic approach exists in the prevention of this phenomenon. The reasons that only some patients with nerve lesions develop neuropathic pain are still unknown. Risk factors such as age, gender, pain intensity before and after the lesion, and emotional and cognitive features indicate that there are multiple factors other than the nerve lesion itself that contribute to the manifestation of chronic pain.

Diagnosis and symptomatic treatment are essential for these patients as painful sensorimotor neuropathies are associated with poor quality of life and autonomic neuropathies are associated with increased cardiovascular mortality.

Intensive diabetes therapy, intensive multifactorial cardiovascular risk reduction and lifestyle intervention are recommended in patients with CAN. The symptomatic treatment of sensory symptoms includes TCAs, SNRIs, gabapentin, pregabalin and opioids. Other treatment strategies are not so effective.

\footnotetext{
References $\quad \nabla_{1}$ Zimmet P, Alberti KG, Shaw J: Global and societal implications of the diabetes epidemic. Nature 2001;414:782-787.

2 Edwards JL, Vincent AM, Cheng HT, Feldman EL: Diabetic neuropathy: mechanisms to management. Pharmacol Ther 2008;120:134.

3 Boulton AJ, Vinik AI, Arezzo JC, Bril V, Feldman EL, Freeman R, Malik RA, Maser RE, Sosenko JM, Ziegler D; American Diabetes Association Diabetic neuropathies: a statement by the American Diabetes Association. Diabetes Care 2005;28:956-962.
} 
-4 Yasuda H, Terada M, Maeda K, Kogawa S, Sanada M, Haneda M, Kashiwagi A, Kikkawa R: Diabetic neuropathy and nerve regeneration. Prog Neurobiol 2003;69:229-285.

5 Duby JJ, Campbell RK, Setter SM, White JR, Rasmussen KA: Diabetic neuropathy: an intensive review. Am J Health Syst Pharm 2004; 61:160-173.

6 Deshpande AD, Harris-Hayes M, Schootman M: Epidemiology of diabetes and diabetes-related complications. Phys Ther 2008;88: 1254-1264.

7 Papanas N, Vinik AI, Ziegler D: Neuropathy in prediabetes: does the clock start ticking early? Nat Rev Endocrinol 2011;7:682-690.

$\checkmark 8$ Fernyhough P, Roy Chowdhury SK, Schmidt RE: Mitochondrial stress and the pathogenesis of diabetic neuropathy. Expert Rev Endocrinol Metab 2010;5:39-49.

-9 Vincent AM, Russell JW, Low P, Feldman EL: Oxidative stress in the pathogenesis of diabetic neuropathy. Endocr Rev 2004;25:612-628.

10 Obrosova IG: How does glucose generate oxidative stress in peripheral nerve? Int Rev Neurobiol 2002;50:3-35.

11 Zherebitskaya E, Akude E, Smith DR, Fernyhough P: Development of selective axonopathy in adult sensory neurons isolated from diabetic rats: role of glucose-induced oxidative stress. Diabetes 2009;58:1356-1364.

$\checkmark 12$ Fernyhough P, Schmidt RE: Neurofilaments in diabetic neuropathy. Int Rev Neurobiol 2002;50:115-144.

13 Baron R, Binder A, Wasner G: Neuropathic pain: diagnosis, pathophysiological mechanisms, and treatment. Lancet Neurol 2010;9: 807-819.

14 Kuwabara S, Misawa S: Pharmacologic intervention in axonal excitability: in vivo assessment of nodal persistent sodium currents in human neuropathies. Curr Mol Pharmacol 2008;1:61-67.

15 Bahia PK, Suzuki R, Benton DC, et al: A functional role for small-conductance calcium-activated potassium channels in sensory pathways including nociceptive processes. J Neurosci 2005;25:3489-98.

16 Caterina MJ, Julius D: The vanilloid receptor: a molecular gateway to the pain pathway. Annu Rev Neurosci 2001;24:487-517.

17 Wen YR, Tan PH, Cheng JK, Liu YC, Ji RR: Microglia: a promising target for treating neuropathic and postoperative pain, and morphine tolerance J Formos Med Assoc 2011;110:487-494.

$\checkmark 18$ Tesfaye S, Selvarajah D: Advances in the epidemiology, pathogenesis and management of diabetic peripheral neuropathy. Diabetes Metab Res Rev 2012;28(suppl 1):8-14

19 Ropper AH, Samuels MA (eds): Adams and Victor's Principles of Neurology, ed 9. New York, McGraw-Hill, 2009, chapter 46.

-20 Bansal V, Kalita J, Misra UK: Diabetic neuropathy. Postgrad Med J 2006;82:95-100.

-21 Abbott CA, Malik RA, van Ross ER, Kulkarni J, Boulton AJ: Prevalence and characteristics of painful diabetic neuropathy in a large com- munity-based diabetic population in the UK. Diabetes Care 2011;34:2220-2224.

-22 Davies M, Brophy S, Williams R, Taylor A: The prevalence, severity, and impact of painful diabetic peripheral neuropathy in type 2 diabetes. Diabetes Care 2006;29:1518-1522.

23 Tracy JA, Dyck PJ: The spectrum of diabetic neuropathies. Phys Med Rehabil Clin N Am 2008;19:1-26.

24 Pop-Busui R: Cardiac autonomic neuropathy in diabetes: a clinical perspective. Diabetes Care 2010;33:434-441.

25 Spallone V, Bellavere F, Scionti L, Maule S, Quadri R, Bax G, Melga P, Viviani GL, Esposito K, Morganti R, Cortelli P; Diabetic Neuropathy Study Group of the Italian Society of Diabetology: Recommendations for the use of cardiovascular tests in diagnosing diabetic autonomic neuropathy. Nutr Metab Cardiovasc Dis 2011;21:69-78.

26 Tesfaye S, Boulton AJ, Dyck PJ, Freeman R, Horowitz M, Kempler P, Lauria G, Malik RA, Spallone V, Vinik A, Bernardi L, Valensi P; Toronto Diabetic Neuropathy Expert Group: Diabetic neuropathies: update on definitions, diagnostic criteria, estimation of severity, and treatments. Diabetes Care 2010;33:22852293.

27 Chandrasekharan B, Srinivasan S: Diabetes and the enteric nervous system. Neurogastroenterol Motil 2007;19:951-960.

28 Price D, Hackett G: Management of erectile dysfunction in diabetes: an update for 2008. Curr Diab Rep 2008;8:437-443.

29 Palumbo PJ: Metabolic risk factors, endothelial dysfunction, and erectile dysfunction in men with diabetes. Am J Med Sci 2007;334: 466-480.

30 Burakgazi AZ, Alsowaity B, Burakgazi ZA, Unal D, Kelly JJ: Bladder dysfunction in peripheral neuropathies. Muscle Nerve 2012;45: 2-8.

31 Freeman R: Autonomic peripheral neuropathy. Lancet 2005;365:1259-1270.

32 American Diabetes Association: Standards of medical care in diabetes - 2011. Diabetes Care 2011;34(suppl 1):S11-S61.

33 Hartemann A, Attal N, Bouhassira D, Dumont I, Gin H, Jeanne S, Said G, Richard JL; Working Group on the Diabetic Foot from the French-speaking Society of Diabetology: Painful diabetic neuropathy: diagnosis and management. Diabetes Metab 2011;37:377388.

- 34 Cruccu G, Sommer C, Anand P, Attal N, Baron R, Garcia-Larrea L, Haanpaa M, Jensen TS, Serra J, Treede RD: EFNS guidelines on neuropathic pain assessment: revised 2009. Eur J Neurol 2010;17:1010-1018.

35 Spallone V, Ziegler D, Freeman R, Bernardi L, Frontoni S, Pop-Busui R, Stevens M, Kempler P, Hilsted J, Tesfaye S, Low P, Valensi P; Toronto Consensus Panel on Diabetic Neuropathy: Cardiovascular autonomic neuropathy in diabetes: clinical impact, assessment, diagnosis, and management. Diabetes Metab Res Rev 2011, DOI: 10.1002/dmrr.1239.
6 Obrosova IG: Diabetic painful and insensate neuropathy: pathogenesis and potential treatments. Neurotherapeutics 2009;6:638-647.

- 37 Hotta N, Akanuma Y, Kawamori R, Matsuoka K, Oka Y, Shichiri M, Toyota T, Nakashima M, Yoshimura I, Sakamoto N, Shigeta Y: Long-term clinical effects of epalrestat, an aldose reductase inhibitor, on diabetic peripheral neuropathy: the 3-year, multicenter, comparative Aldose Reductase Inhibitor-Diabetes Complications Trial. Diabetes Care 2006;29:1538-1544.

38 Hotta N, Toyota T, Matsuoka K, Shigeta Y, Kikkawa R, Kaneko T, Takahashi A, Sugimura K, Koike Y, Ishii J, Sakamoto N; SNK-860 Diabetic Neuropathy Study Group: Clinical efficacy of fidarestat, a novel aldose reductase inhibitor, for diabetic peripheral neuropathy: a 52-week multicenter placebo-controlled double-blind parallel group study. Diabetes Care 2001;24:1776-1782.

39 Hotta N, Yasuda K, Sumita Y, Sano T, Kakuta H, Nagashima M, Hayashi Y, Yamamoto M, Wakao T, Okuyama M, Kobayashi M, Mori K: Effects of a novel aldose reductase inhibitor, fidarestat (SNK-860), on vibration perception threshold and subjective symptoms in patients with diabetic polyneuropathy: an openlabel pilot study. Clin Drug Investig 2004;24: 671-680.

40 Bril V, Buchanan RA: Long-term effects of ranirestat (AS-3201) on peripheral nerve function in patients with diabetic sensorimotor polyneuropathy. Diabetes Care 2006;29:68-72.

41 Chalk C, Benstead TJ, Moore F: Aldose reductase inhibitors for the treatment of diabetic polyneuropathy. Cochrane Database Syst Rev 2007;4:CD004572.

42 Mijnhout GS, Alkhalaf A, Kleefstra N, Bilo HJ: Alpha lipoic acid: a new treatment for neuropathic pain in patients with diabetes? Neth J Med 2010;68:158-162.

43 Ziegler D, Nowak H, Kempler P, Vargha P, Low PA: Treatment of symptomatic diabetic polyneuropathy with the antioxidant alphalipoic acid: a meta-analysis. Diabet Med 2004; 21:114-121.

44 McIlduffCE, Rutkove SB: Critical appraisal of the use of alpha lipoic acid (thioctic acid) in the treatment of symptomatic diabetic polyneuropathy. Ther Clin Risk Manag 2011;7: 377-385.

45 Ziegler D, Hanefeld M, Ruhnau KJ, Hasche H, Lobisch M, Schütte K, Kerum G, Malessa R; ALADIN III Study Group: Treatment of symptomatic diabetic polyneuropathy with the antioxidant $\alpha$-lipoic acid: a 7-month multicenter randomized controlled trial (ALADIN III Study). Diabetes Care 1999;22:12961301.

46 Ziegler D, Low PA, Litchy WJ, Boulton AJ, Vinik AI, Freeman R, Samigullin R, Tritschler H, Munzel U, Maus J, Schütte K, Dyck PJ: Efficacy and safety of antioxidant treatment with $a$-lipoic acid over 4 years in diabetic polyneuropathy: the NATHAN 1 trial. Diabetes Care 2011;34:2054-2060. 
-47 Mijnhout GS, Kollen BJ, Alkhalaf A, Kleefstra N, Bilo HJ: Alpha lipoic acid for symptomatic peripheral neuropathy in patients with diabetes: a meta-analysis of randomized controlled trials. Int J Endocrinol 2012;2012:456279.

-48 Said G: Diabetic neuropathy - a review. Nat Clin Pract Neurol 2007;3:331-340.

49 Bril V, England J, Franklin GM, Backonja M, Cohen J, Del Toro D, Feldman E, Iverson DJ, Perkins B, Russell JW, Zochodne D: Evidence-based guideline: treatment of painful diabetic neuropathy: report of the American Academy of Neurology, the American Association of Neuromuscular and Electrodiagnostic Medicine, and the American Academy of Physical Medicine and Rehabilitation. Neurology 2011;76:1758-1765.

- 50 Attal N, Cruccu G, Baron R, Haanpää M, Hansson P, Jensen TS, Nurmikko T; European Federation of Neurological Societies: EFNS guidelines on the pharmacological treatment of neuropathic pain: 2010 revision. Eur J Neurol 2010;17:1113-e88.

51 Feighner JP: Mechanism of action of antidepressant medications. J Clin Psychiatry 1999; 60(suppl 4):4-11.

52 Dworkin RH, Backonja M, Rowbotham MC, Allen RR, Argoff CR, Bennett GJ, Bushnell MC, Farrar JT, Galer BS, Haythornthwaite JA, Hewitt DJ, Loeser JD, Max MB, Saltarelli M, Schmader KE, Stein C, Thompson D, Turk DC, Wallace MS, Watkins LR, Weinstein SM: Advances in neuropathic pain diagnosis, mechanisms, and treatment recommendations. Arch Neurol 2003;60:1524-1534.

-53 Saarto T, Wiffen PJ: Antidepressants for neuropathic pain: a Cochrane review. J Neurol Neurosurg Psychiatry 2010;81:1372-1373.

- 54 Haanpää ML, Gourlay GK, Kent JL, Miaskowski C, Raja SN, Schmader KE, Wells CD: Treatment considerations for patients with neuropathic pain and other medical comorbidities. Mayo Clin Proc 2010;85(3 suppl):S15-S25.

55 Trindade E, Menon D, Topfer LA, Coloma C: Adverse effects associated with selective serotonin reuptake inhibitors and tricyclic antidepressants: a meta-analysis. CMAJ 1998;159: 1245-1252.

56 Roose SP, Laghrissi-Thode F, Kennedy JS, Nelson JC, Bigger JT Jr, Pollock BG, Gaffney A, Narayan M, Finkel MS, McCafferty J, Gergel I: Comparison of paroxetine and nortriptyline in depressed patients with ischemic heart disease. JAMA 1998;279:287-291.

57 Jiang W, Davidson JR: Antidepressant therapy in patients with ischemic heart disease. Am Heart J 2005;150:871-881

-58 Saarto T, Wiffen PJ: Antidepressants for neuropathic pain. Cochrane Database Syst Rev 2007;4:CD005454.

59 Max MB, Lynch SA, Muir J, Shoaf SE, Smoller B, Dubner R: Effects of desipramine, amitriptyline, and fluoxetine on pain in diabetic neuropathy. N Engl J Med 1992;326:1250-1256.

-60 Sindrup SH, Gram LF, Brosen K, Eshoj O, Mogensen EF: The selective serotonin reup- take inhibitor paroxetine is effective in the treatment of diabetic neuropathy symptoms. Pain 1990;42:135-144.

61 Sindrup SH, Bjerre U, Dejgaard A, Brøsen K, Aaes-Jørgensen T, Gram LF: The selective serotonin reuptake inhibitor citalopram relieves the symptoms of diabetic neuropathy. Clin Pharmacol Ther 1992;52:547-552.

62 Stahl SM, Grady MM, Moret C, Briley M: SNRIs: their pharmacology, clinical efficacy, and tolerability in comparison with other classes of antidepressants. CNS Spectr 2005;10:732-747.

63 Lunn MP, Hughes RA, Wiffen PJ: Duloxetine for treating painful neuropathy or chronic pain. Cochrane Database Syst Rev 2009; 4:CD007115

64 Hall JA, Wang F, Oakes TM, Utterback BG, Crucitti A, Acharya N: Safety and tolerability of duloxetine in the acute management of diabetic peripheral neuropathic pain: analysis of pooled data from three placebo-controlled clinical trials. Expert Opin Drug Saf 2010;9: 525-537.

65 Vinik A: Clinical review: use of antiepileptic drugs in the treatment of chronic painful diabetic neuropathy. J Clin Endocrinol Metab 2005;90:4936-4945.

66 LaRoche SM, Helmers SL: The new antiepileptic drugs: scientific review. JAMA 2004,291:605-614.

67 Wiffen PJ, McQuay HJ, Edwards JE, Moore RA: Gabapentin for acute and chronic pain. Cochrane Database Syst Rev 2005;3:CD005452.

68 Moore RA, Wiffen PJ, Derry S, McQuay HJ: Gabapentin for chronic neuropathic pain and fibromyalgia in adults. Cochrane Database Syst Rev 2011;3:CD007938.

69 Moore RA, Straube S, Wiffen PJ, Derry S, McQuay HJ: Pregabalin for acute and chronic pain in adults. Cochrane Database Syst Rev 2009;3:CD007076.

70 Gill D, Derry S, Wiffen PJ, Moore RA: Valproic acid and sodium valproate for neuropathic pain and fibromyalgia in adults. Cochrane Database Syst Rev 2011;10:CD009183.

71 Wiffen PJ, Derry S, Moore RA: Lamotrigine for acute and chronic pain. Cochrane Database Syst Rev 2011;2:CD006044.

-72 Wiffen PJ, Derry S, Moore RA, McQuay HJ: Carbamazepine for acute and chronic pain in adults. Cochrane Database Syst Rev 2011; 1:CD005451

73 Thienel U, Neto W, Schwabe SK, Vijapurkar U; Topiramate Diabetic Neuropathic Pain Study Group: Topiramate in painful diabetic polyneuropathy: findings from three doubleblind placebo-controlled trials. Acta Neurol Scand 2004;110:221-231.

74 Donofrio PD, Raskin P, Rosenthal NR, Hewitt DJ, Jordan DM, Xiang J, Vinik AI; CAPSS-141 Study Group: Safety and effectiveness of topiramate for the management of painful diabetic peripheral neuropathy in an open-label extension study. Clin Ther 2005;27:1420-1431.

75 Eisenberg E, McNicol E, Carr DB: Opioids for neuropathic pain. Cochrane Database Syst Rev 2006;3:CD006146.
76 Furlan AD, Sandoval JA, Mailis-Gagnon A, Tunks E: Opioids for chronic noncancer pain: a meta-analysis of effectiveness and side effects. CMAJ 2006;174:1589-1594.

77 J Zeilhofer HU, Witschi R, Hösl K: Subtypeselective $\mathrm{GABA}_{\mathrm{A}}$ receptor mimetics - novel antihyperalgesic agents? Mol Med (Berl) 2009;87:465-469.

78 Smith HS, Argoff CE: Pharmacological treatment of diabetic neuropathic pain. Drugs 2011;71:557-589.

79 Zhang C, Ma YX, Yan Y: Clinical effects of acupuncture for diabetic peripheral neuropathy. J Tradit Chin Med 2010;30:13-14.

80 Hopton A, MacPherson H: Acupuncture for chronic pain: is acupuncture more than an effective placebo? A systematic review of pooled data from meta-analyses. Pain Pract 2010;10: 94-102.

81 Chen W, Zhang Y, Liu JP: Chinese herbal medicine for diabetic peripheral neuropathy. Cochrane Database Syst Rev 2011; 6:CD007796

82 Dubinsky RM, Miyasaki J: Assessment: efficacy of transcutaneous electric nerve stimulation in the treatment of pain in neurologic disorders (an evidence-based review): report of the Therapeutics and Technology Assessment Subcommittee of the American Academy of Neurology. Neurology 2010;74:173176

83 Quilici S, Chancellor J, Löthgren M, Simon D, Said G, Le TK, Garcia-Cebrian A, Monz B: Meta-analysis of duloxetine vs. pregabalin and gabapentin in the treatment of diabetic peripheral neuropathic pain. BMC Neurol 2009;9:6

84 Chou R, Carson S, Chan BK: Gabapentin versus tricyclic antidepressants for diabetic neuropathy and post-herpetic neuralgia: discrepancies between direct and indirect meta-analyses of randomized controlled trials. J Gen Intern Med 2009;24:178-188.

85 Wolff RF, Bala MM, Westwood M, Kessels AG, Kleijnen J: 5\% lidocaine medicated plaster in painful diabetic peripheral neuropathy (DPN): a systematic review. J Swiss Med Wkly 2010;140:297-306.

86 Tesfaye S, Wilhelm S, Lledo A, Schacht A, Tölle T, Bouhassira D, Cruccu G, Skljarevski V, Freynhagen R: Duloxetine and pregabalin: high-dose monotherapy or their combination? The 'COMBO-DN study' - a multinational, randomized, double-blind, parallelgroup study in patients with diabetic peripheral neuropathic pain. Pain 2013;154: 2616-2625.

87 Kempler P, Amarenco G, Freeman R, Frontoni S, Horowitz M, Stevens M, Low P, PopBusui R, Tahrani A, Tesfaye S, Várkonyi T, Ziegler D, Valensi P; Toronto Consensus Panel on Diabetic Neuropathy: Gastrointestinal autonomic neuropathy, erectile-, bladderand sudomotor dysfunction in patients with diabetes mellitus: clinical impact, assessment, diagnosis, and management. Diabetes Metab Res Rev 2011, DOI: 10.1002/dmrr.1223. 